Chapman University

Chapman University Digital Commons

Business Faculty Articles and Research

Business

$11-17-2004$

\title{
Entrepreneurial Orientation as a Basis for Classification within a Service Industry: The Case of Retail Pharmacy Industry
}

Thanigavelan Jambulingam

St. Joseph's University

Ravi Kathuria

Chapman University, kathuria@chapman.edu

William R. Doucette

University of lowa

Follow this and additional works at: https://digitalcommons.chapman.edu/business_articles

Part of the Business Administration, Management, and Operations Commons, Other Business Commons, Other Pharmacy and Pharmaceutical Sciences Commons, Pharmacoeconomics and Pharmaceutical Economics Commons, Pharmacy Administration, Policy and Regulation Commons, and the Sales and Merchandising Commons

\section{Recommended Citation}

Jambulingam, T., Kathuria, R., \& Doucette, W. R. (2005). Entrepreneurial orientation as a basis for classification within a service industry: The case of retail pharmacy industry. Journal of Operations Management, 23(1), 23-42. doi: 10.1016/j.jom.2004.09.003

This Article is brought to you for free and open access by the Business at Chapman University Digital Commons. It has been accepted for inclusion in Business Faculty Articles and Research by an authorized administrator of Chapman University Digital Commons. For more information, please contact laughtin@chapman.edu. 


\section{Entrepreneurial Orientation as a Basis for Classification within a Service Industry: The Case of Retail Pharmacy Industry}

\section{Comments}

NOTICE: this is the author's version of a work that was accepted for publication in Journal of Operations Management. Changes resulting from the publishing process, such as peer review, editing, corrections, structural formatting, and other quality control mechanisms may not be reflected in this document. Changes may have been made to this work since it was submitted for publication. A definitive version was subsequently published in Journal of Operations Management, volume 23, issue 1, in 2005. DOI: 10.1016/j.jom.2004.09.003

The Creative Commons license below applies only to this version of the article.

\section{Creative Commons License}

\section{(c) (1) (9)}

This work is licensed under a Creative Commons Attribution-Noncommercial-No Derivative Works 4.0 License.

\section{Copyright}

Elsevier 
Entrepreneurial Orientation as a Basis for Classification within a Service Industry:

The Case of Retail Pharmacy Industry

\author{
Thanigavelan Jambulingam \\ Department of Marketing \\ Erivan K. Haub School of Business \\ St. Joseph's University \\ 5600 City Avenue \\ Philadelphia, PA 19131-1395 \\ Phone: (610)-660-3382 \\ e-mail: tjambuli@sju.edu
}

\author{
Ravi Kathuria* \\ Argyros School of Business and Economics \\ Chapman University \\ One University Drive \\ Orange, CA 92866 \\ Phone: (714) 628-2703 \\ Fax: (714) 532-6081 \\ email: kathuria@chapman.edu
}

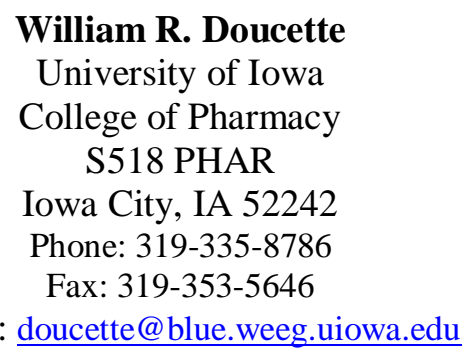

*Corresponding author

Submitted to the Journal of Operations Management

Revision submitted: February 10, 2004

Second revision: August 19, 2004 


\title{
Entrepreneurial Orientation as a Basis for Classification within a Service Industry: The Case of Retail Pharmacy Industry
}

\begin{abstract}
To date, service classification research has primarily taken a macro view, creating service typologies or taxonomies by using dimensions such as customer contact or degree of labor intensity. Such classification schemes, though helpful in deciphering critical management issues and positioning strategies between service industries, tend to treat an entire industry, such as airlines, as a single homogenous entity. However, organizations in the same industry often use intangible resources, such as entrepreneurial orientation processes, to compete with one another. Resource-Advantage Theory suggests that organizations utilize intangible resources to build long-term strategies and a sustainable competitive advantage leading to superior performance. We developed organization clusters based on entrepreneurial orientation as intangible resources to classify organizations within a retailing industry. Using data from the retail pharmacy industry, we tested if the entrepreneurial orientations of the resultant groups within the pharmacy industry were related to their perception of the environment, organizational factors, and performance outcomes. The operationalization of the construct of entrepreneurial orientation is one of the contributions of the study.
\end{abstract}

Key Words: Service Management; Entrepreneurial Orientation, Intangible Resources; Operations Strategy; Competitive Advantage; Classification Scheme; Taxonomy. 
To date, service classification research has primarily taken a macro view, creating service typologies or taxonomies by using dimensions such as customer contact (cf., Chase 1978), degree of labor intensity (cf., Schmenner 1986; Haywood-Farmer 1988), delivery channels (Huete and Roth 1988), nature of service products and service processes (Kellogg and Nie 1995). These typologies - commonly used in service management textbooks - tend to classify services using one or more attributes (cf., Fitzsimmons and Fitzsimmons 2001). For example, using the customer contact dimension, health care is classified as a high contact service and the postal service as low contact. Lovelock (1983) classifies services in several two-by-two matrices, which help with understanding how the nature of services in each class affects marketing and operations. Most of these classification schemes have been accepted on the basis of their intuitive appeal, and often lack empirical verification (Cook, Goh and Chung 1999). Cook et al. (1999) presented a concise view of the service classification literature, and provided an integrated schematic representation that captures various important dimensions of the service classification schemes in both marketing and operations disciplines.

Among the early classification schemes that were developed or verified empirically, Silvestro, Fitzgerald, Johnston, and Voss (1992) is notable. They derived a service taxonomy based on the volume of daily service activity and six classification dimensions - length of customer contact time, degree of customization, level of employee discretion, value added, product/process focus, and labor intensity. Depending upon a firm’s daily service activity and its ranking on the six dimensions, it would be classified as a professional service, service shop, or a mass service.

These schemes supposedly help the managers in "assessing the demands placed on the service system in terms of its operating requirements” (Cook et al. 1999, p. 328). The 
classification schemes, though helpful in deciphering critical management issues and positioning strategies for different service industries or classes of organizations, tend to classify an entire industry, such as airlines, as one type. Such classifications are useful, but do not take into account the differences within an industry. Verma and Young (2000) concur with our views and contend that these classification schemes fail to recognize the differences within a specific category of service businesses, such as service factory, service shop, and professional service.

Heeding the advice of researchers in operations management (cf., Chase 1996; Swamidass 1991; Flynn, Sakakibara, Schroeder, Bates, and Flynn 1990; Boyer, Bozarth, and McDermott 2000) to empirically validate the generally accepted typologies and frameworks, Verma and Boyer (2000) conducted an empirical examination of the management challenges faced by managers in four different types of services based on Schmenner's (1986) service process matrix. Using data from the pizza industry, Verma, Thomson, and Louviere (1999) presented an approach to configure service operations by integrating market-based objectives and operating decisions of managers. Verma and Young (2000) developed a taxonomy for one type of service - low contact services. They, however, included two different service industries - fast food restaurants and auto repair services - in their study to develop a common taxonomy for both the industries. They discovered five clusters based on the relative importance given to what they called the operational, market and financial objectives.

Metters and Vargas (2000) presented a typology for competitive positioning with respect to strategic operations focus and “de-coupling” activity. They used one industry - the retail bank lending industry - to exemplify the ideal types presented in their typology. Recently, Menor, Roth and Mason (2002) developed a taxonomy of strategic service groups within one industry retail banking. Along those lines, our study is focused on one industry - retail pharmacy 
industry. We conducted a study of the retail pharmacy industry to identify clusters of retail pharmacies, based on the entrepreneurial orientation as intangible resources they use in their strategies. The specific objectives of this study were to 1) derive a service provider taxonomy based on entrepreneurial orientation (intangible resources) utilized by retail pharmacies and 2) characterize the environmental, organizational and performance features of the clusters of retail pharmacies identified through the taxonomy.

\section{BACKGROUND AND RESEARCH CONTEXT}

If we were to use earlier classification schemes, such as Chase's (1978), we would classify all pharmacies as service shops. The popular literature, however, classifies retail pharmacies based upon the number of stores and type of merchandise sold. For example, “independent pharmacies” have less than four stores and "small chain” pharmacies have four to ten stores under a chain. "Large chains" are comprised of more than ten stores. "Food and drug combos," are food stores with an in-house pharmacy, such as Kroger and Pathmark. "Mass merchandisers,” are retail stores with pharmacies, such as Kmart. These pharmacies utilize different combinations of resources to compete through variations in services.

The results of a consumer survey lend support to the above-mentioned argument that different types of pharmacies (independents, mass merchandise, food and drug chains) use different competitive priorities: service level, information, and speed (Consumer Reports 1999). Their ratings indicated that the independents, in general, provide a high level of service (pharmacists courteous, helpful, and accessible) and at a faster speed (without delays) compared to most large chain pharmacies, food \& drug stores, and mass merchandisers. But, one large chain, Medicine Shoppe (1,200 stores nationwide) was found to be as good a service provider, 
and came very close on the speed of service to the independents. Thus, differences may exist not only across sub-groups within an industry (e.g., independents vs. mass merchandisers), but within the subgroups in that industry. This points to the need for a means of classifying service providers more effectively.

It is apparent that retail pharmacies utilize a variety of long-term strategies (i.e. intangible resources) to stay competitive over time. Some pharmacies develop combinations of intangible resources that can create services that add to their competitive position. Rather than a traditional scheme to classify such an industry, we propose a system based on combinations of intangible resources.

\section{THEORETICAL CONCEPTUALIZATION}

The theoretical underpinning for this study is based on the resource-advantage (RA) theory. Recent literature (cf., Priem and Butler 2001) indicates that the resource advantage theory proposed by Hunt and Morgan $(1995,1996)$ is considered more robust compared to the resourcebased view (Barney 1991) of the firm. Service strategy researchers (cf., Roth and Jackson 1995; Menor, Roth, and Mason 2002) are just beginning to empirically study the resource-based view. The resource-advantage theory, an advancement over the resource-based view perspective, proposes that superior performance results from a competitive advantage in resources, which was defined as "tangible or intangible entities available to firms that enable them to produce efficiency and/or effective market offerings that have value to some market segments” (Hunt and Morgan 1996). Therefore, competition is the ongoing struggle among firms for a comparative advantage in resources that will yield marketplace positions of competitive advantage and, thereby, superior performance. RA theory recognizes organizations’ entrepreneurial capabilities as organizational resources. Since a competitive advantage is hard to sustain unless it is based on 
resources that are valuable, rare, imperfectly imitable, and not easily substituted (Barney 1991), retail pharmacies need to have a strategic, long-term focus on the development and delivery of new and innovative services to stay competitive in the long run. That is, they establish intangible resources, such as a strategy of entrepreneurial orientation.

The successful development and delivery of services often depends upon entrepreneurial orientation of an organization in consonance with its long-term goals. Organizational resources can be tangible, such as facilities, equipment, goods, and human capital. Also, intangible resources can be developed, such as organizational processes, routines, knowledge, intelligence, and reputation of the organization. Because of their complexity, intangible resources often are difficult to imitate and can be critical to an organization’s performance.

Entrepreneurial orientation is defined as the processes, practices, and decision-making activities that lead to the development and delivery of new and innovative services that can differentiate an organization from others in its market (Lumpkin and Dess 1996). The dimensions of entrepreneurial orientation include a firm's ability and willingness to: 1) innovate (innovativeness), 2) take action in anticipation of changes (proactiveness), 3) encourage independent activity by employees (autonomy), 4) respond to maneuvers of rivals (competitive aggressiveness), 5) take chances (risk taking), and 6) motivate employees to work hard and face challenges (motivation). Firms might possess different levels of these intangible resources in a market place. 


\section{HYPOTHESES}

Innovativeness is defined as an organization's tendency to engage in and support new ideas, novelty, experimentation, and creative processes that may result in new services (Lumpkin and Dess 1996). It reflects an important way in which organizations address new opportunities. Proactiveness refers to a firm's processes aimed at anticipating and acting on future needs (Venkatraman 1989). Autonomy refers to the extent to which all employees of an organization have freedom to bring forth an idea or vision and carrying it through to completion. For example, the presence of a champion can facilitate the development of new services. Competitive aggressiveness represents an organization's propensity to directly and intensely challenge its competitors to achieve entry or improve market position (Lumpkin and Dess 1996). In contrast to proactiveness, competitive aggressiveness captures the reactive tendencies of a firm.

Risk taking refers to a firm’s proclivity to engage in risky projects and reflects managers’ preferences for bold acts to achieve organizational objectives (Gasse 1982). The logic is that a willingness to take risks will contribute to an organization's desire to develop and deploy new ideas to deliver the service. Motivation denotes an organization's ability to enhance employees’ attitude and morality toward work. Favorable attitudes toward and moral belief in hard work will contribute to employees’ motivation toward a high level of job performance.

The traditional taxonomy for the pharmacy industry is based on firm size, and product/service mix. For example, the number of retail outlets containing a pharmacy department is one metric for categorizing organizations in the industry (e.g. independent vs. small chain vs. large chain). Similarly, product/service mix is a common criterion for classifying organizations in this industry, as well as many others (mass merchandiser vs. food stores vs. pharmacy). Yet, these traditional approaches may not distinguish adequately among firms in an industry. For 
example, the merchandise and service mix at Walgreens (chain pharmacy) and Wal-Mart (mass merchandiser) overlaps to a considerable degree. We believe that a taxonomy based on intangible resources, such as innovativeness and risk taking, will provide a more meaningful categorization among firms in an industry. This brings us to our first two hypotheses.

H1: Organizations within an industry can be classified based on their willingness and ability to be innovative, proactive, autonomous, competitive aggressive, risk taking, and motivating.

H2: A taxonomy of service providers based on an organization's willingness and ability to be innovative, proactive, autonomous, competitive aggressive, risk taking, and motivating is not related to a traditional taxonomy based on size and product/service mix.

The development and delivery of new and innovative services would depend upon a firm's ability to utilize information about its environment to enhance the success of strategic decisions (e.g. offering new services). In the literature, two classes of factors have been associated with such propensity: environmental factors and organizational factors (Lumpkin and Dess 1996; Covin and Slevin 1991). Environmental factors are external to an organization, and typically have been treated as dimensions that characterize abstract qualities confronting managers (Doucette, Schommer, and Wiederholt 1993). Three environmental dimensions that have been associated with entrepreneurial characteristics described above are environmental stability (also known as dynamism), munificence, and competitive intensity (Covin and Slevin 1991; Miller 1983; Lumpkin and Dess 1996, 2001). Similar environmental factors have been used in studies in the operations literature (cf., Ward, Duray, Leong, and Sum 1995).

Environmental stability reflects high predictability of future influences in the marketplace (Miller and Friesen 1978; Achrol and Stern 1988; Duncan 1972). For example, a pharmacy in a dynamic or less stable environment may have difficulty predicting the actions of competitors, the influence of managed care on demand for its services, or the preferences of consumers. Firms 
have been shown to respond to less stable environments by adopting the aforesaid entrepreneurial characteristics as a strategy (Covin and Slevin 1991; Khandwalla 1987). The logic is that when competitors change their product offerings rapidly or if consumer needs fluctuate, new goods and services are needed to compete successfully.

It is likely that organizations can respond well to less stable environments if they possess more intangible resources such as risk taking, innovativeness, and proactiveness. For example, a pharmacy that is high on these entrepreneurial characteristics will be attuned to ongoing changes in its environment and will work to develop services that will create a competitive advantage.

Munificence refers to the extent to which an environment can support sustained growth (Dess and Beard 1984; Starbuck 1976; Pfeffer and Salancik 1978). A firm exists in a munificent environment when it is able to identify adequate opportunities for growth. The argument here is that a munificent environment allows a firm to develop slack resources (Cyert and March 1963). Slack resources are uncommitted resources that can be used with discretion. They provide the means for organizational innovation (Bourgeois 1981; Chakravarthy 1982) as deemed necessary to stay competitive in the long run.

In a similar manner, a pharmacy in a munificent environment could develop slack resources. Then, profits might be invested in improving the expertise of its personnel in developing new services or providing a higher level of service. Further, resources could be used to support trials of new services, in a market-testing mode.

The competitive intensity of a firm's environment refers to the level of competition among firms in a market (Covin and Slevin 1989). The pharmacies that are more competitive aggressive, proactive and innovative are likely to perceive their environment to be intensely competitive, and vice versa. Under such a perception, a firm develops innovative goods and 
services, in order to create a competitive advantage (Miller and Friesen 1982). Adopting this logic, we hypothesize the following relationship:

H3: Based on different combinations of intangible resources, various classes of organizations will perceive the environmental factors of munificence, competitive intensity and environmental stability differently.

In addition to environmental factors, organizational factors could influence a firm's ability to develop and utilize intangible resources such as innovativeness, proactiveness and risk taking. Three organizational factors of interest are: organicity, adaptability, and the tolerance for ambiguity. Organicity is defined as an organization's use of informal control and cooperation to govern their employees (Lumpkin and Dess 1996). Organic firms are likely to be innovative, since they possess the flexibility needed to pursue and develop new product offerings. Similarly, an organic structure will support autonomy among employees, due to its tendency to avoid centralized decision-making.

Adaptability is defined as the willingness to change as the business environment changes (Lumpkin and Dess 1996). Firms that tend to be more proactive, competitive aggressive, and risk taking are expected to be more adaptable. Proactiveness and competitive aggressiveness require awareness of the firm's environment and an ability to react to it. These intangible resources will support adaptability. Similarly, a willingness to adapt to forces in the environment carries an element of risk taking.

Tolerance for ambiguity is defined as the willingness and ability to handle a vague situation (Lumpkin and Dess 1996). Firms that intend to develop new services (e.g. innovativeness) are more likely to face, and be more willing to handle, a vague situation than those who prefer status quo. Similarly, firms that possess risk taking are likely to be able to tolerate ambiguity in their situation. This logic brings us to our next hypothesis: 
H4: Classes of organizations based on combinations of intangible resources will vary in their utilization of the organizational factors of organicity, adaptability and tolerance for ambiguity differently.

Researchers in operations strategy (cf., Richardson, Taylor, and Gorden 1985; Giffi, Roth, and Seal 1990) suggest a correspondence between an organization's competitive orientation and performance (Miller and Roth 1994, Noble 1995, Kathuria 2000). Consistent with that line of thinking, we expect various groups based on the new classification scheme in Hypothesis 1 to show better performance on measures consistent with their orientation. The performance measures used in this study were effectiveness, customer orientation, respondent's perception of growth compared to the largest competitor, and the number of innovative services provided by the pharmacy. The new classification based on entrepreneurial orientation, unlike the traditional classification, should provide performance outcomes consistent with their orientation. For example, an organization that is more risk taking and innovative will perform better on the number of innovative services provided.

Effectiveness was defined as the organization's ability to consistently meet organizational goals and performance objectives. Customer orientation was defined as the organization's ability to meet customer needs through the services provided, and to keep customers' interests ahead of the owners'. Depending upon an organization's orientation in terms of risk taking, innovativeness, proactiveness, autonomy, competitive aggressiveness and motivation, we expect different groups to focus on and perform better on performance dimensions consistent with their orientation. Thus,

H5: Based on different combinations of intangible resources, different classes of organizations will perform better on different sets of performance criteria. 


\section{METHODS}

\section{Retail Pharmacy Industry}

U.S. Health Care Financing Administration estimated the GDP spending on healthcare in 2001 to be $14.6 \%$ or 1.4 trillion dollars (NWDA 2000). National expenditures on prescription drugs for 2002 have been estimated to exceed \$160 billion (www.cms.gov). Retail pharmacies distribute the majority of these drugs to patients. In 2001 retail pharmacies distributed about 129.6 billion dollars worth of products and about 3.14 billion prescriptions (NDC Health 2002)

The retail pharmacy industry traditionally can be described using firm size and product/service mix criteria. Sole units are comprised primarily of independent pharmacies, usually owned by pharmacists. Other sole units can be outlets operated by larger organizations, such as a hospital or clinic. Multiple-unit pharmacy organizations, or chains, can be divided into small chain and large chain (e.g. 30 or more units).

In addition to firm size, the retail pharmacy industry can be characterized by the product/service mix of the firms, though there is some blurring of this distinction. Some traditional categories include mass merchandiser (e.g. Wal-Mart, Target), supermarket (e.g. Albertsons, Safeway), and drug stores (e.g. Walgreens, CVS). In 2002, the 55,000 retail pharmacy outlets were comprised of about 20,000 drug store units, over 19,000 independents, almost 9,000 supermarket units, and more than 6,000 mass merchandise units (National Association of Chain Drug Stores, “Community Retail Pharmacy Outlets by Type of Store, 1991-2002,” http://www.nacds.org/user-assets/PDF files/Retail Outlets.pdf, Accessed 02-032004.)

Pharmacies or drug stores used to be profitable business up until the mid-1980s when managed care became dominant. Now, managed care pays for about $75 \%$ of all prescriptions, 
and in 1997, 64 percent of Americans belonged to a managed care organization (Consumer Reports 1999). The insurance companies are believed to have cut back pharmacy profits to less than half what they were a decade ago. Further, with the onslaught of on-line drug stores, and mail-order pharmacies, the pharmacy industry is becoming more competitive than ever.

\section{Data and procedures}

A mail survey was sent to a random sample of 630 pharmacies from nine states, with at least one each from the nine U.S. Census divisions. The survey was addressed to the pharmacy manager, accompanied by a non-personalized cover letter, a stamped return envelope, and a $\$ 1$ token incentive.

The sample included different types of pharmacies to facilitate generalizability of the results within the pharmacy industry. The focus of this study was a pharmacy, including independent pharmacies, a variety of retail chains, and hospital pharmacies. The type of pharmacy was determined by asking the respondent to self-classify the pharmacy into one of six categories: independent, small pharmacy chain (less than 11 units), large pharmacy chain, fooddrug combination chain, mass merchandise chain or outpatient hospital pharmacy.

\section{Measures}

All measures used in the study were developed by the authors and tested for the first time. The survey contained four items each to assess the six intangible resources, four items to measure environmental munificence, and a four-item measure of competitive intensity. Organicity and adaptability each were measured with a three-item scale, and tolerance for ambiguity with a four-item scale. These items were assessed with a 7-point Likert scale (1- 
Strongly Disagree / 7-Strongly Agree). Environmental stability was measured with five items that asked about the predictability of the pharmacy's business environment. A 5-point scale was used (1-Very Low, 2-Low, 3-Medium, 4-High, 5-Very High).

The outcome measures of customer orientation and effectiveness were measured using a three-item scale each. Each item was assessed on a 7-point Likert scale (1-Strongly Disagree / 7Strongly Agree). The growth measure used a single item 3-point scale to rate the pharmacy relative to the largest competitor of the respondent (1-Less/2-Similar/3-More). The respondents were also provided with a list of ten innovative pharmacy services and were asked if they provided those services or not. The total number of innovative services provided by a pharmacy was used as a performance measure, with the expectation that the more entrepreneurial pharmacies would provide a higher number of services. One item asked about the position of the respondent within the pharmacy, and another about their level of involvement (1-Very low - 5Very high involvement) in the pharmacy.

\section{Data Analyses}

A principal component factor analysis with oblimin rotation in SPSS 10.0 was used to assess the unidimensionality of the intangible resource measures. The oblimin rotation was used since these dimensions are not assumed to be orthogonal, but may actually be supportive of each other. To ensure that a given item represented the construct underlying each factor, a two-stage rule was used (cf., Nunnally 1978). First, a factor weight of 0.45 was used as the minimum cutoff. Second, if an item loaded on more than one factor, with difference between weights less than 0.10 across factors, the item was deleted from the final scale. Next, the internal consistency of the scales was assessed using Cronbach's alpha coefficients. 
To create groups of pharmacies with similar combinations of intangible resources, the data were cluster analyzed using Ward's method with the squared Euclidean distance measure in SPSS 10.0, also deployed by Noble (1995) and Frohlich and Dixon (2001), among others. Ward's method is widely used for its robustness, capability to recover known cluster structure, and ability to maximize with-in cluster homogeneity and between cluster heterogeneity (Aldenderfer and Blashfield, 1984). A problem with the cluster analysis, however, is the selection of the most appropriate number of clusters (Miller and Roth 1994). The objective, generally, is to strike a balance between parsimony (few clusters) and accuracy that is attained by keeping the data as individual observations (Boyer, Ward, and Leong 1996). This study used several rules of thumb as guides for determining the appropriate number of clusters, as employed in similar studies by Miller and Roth (1994), Boyer, Ward, and Leong (1996), Kathuria (2000), and Menor, Roth, and Mason (2002).

First, Lehmann (1979) suggests that the number of clusters should be limited to between $\mathrm{n} / 30$ and $\mathrm{n} / 60$, where $\mathrm{n}$ is the sample size. This implies that the number of clusters in the final analysis should be between four and eight. Second, a hierarchical clustering model was used to generate a dendogram, which graphically illustrated how the pharmacies quickly grouped into six main clusters. Third, to check the stability of membership in the six clusters, three iterations of the Ward's method were performed with the number of clusters set at five, six, and seven. A comparison of the three solutions indicated that the cluster membership was stable across solutions and new clusters were formed only by splitting apart larger clusters. Fourth, Ward's clustering method was run several times after rearranging the observations, based on several keys. Since the shuffling of observations did not affect the cluster membership in any way, it was concluded that the six-cluster solution identified by the Ward's method was, indeed, a robust solution.

Finally, the managerial interpretability of the solutions was sought. First, ANOVA was used to test for differences in the defining variables (the entrepreneurial orientation), among 
clusters. Second, Tukey HSD pairwise comparisons of means were performed to determine which pairs were significantly different.

\section{RESULTS AND DISCUSSION}

Fifteen of the surveys mailed out were undeliverable. Of the 615 surveys delivered, 251 (40.8\%) were returned in analyzable form. The numbers of pharmacy types were: independent (105), small pharmacy chain [less than 11 units] (23), large pharmacy chain (54), food-drug combination chain (34), mass merchandise chain (18), and outpatient hospital pharmacies (17). The proportion of pharmacy types in our sample was not significantly different from that of the population statistics obtained from the National Council for Prescription Drug Programs files (Chi-squared 0.498, p-value=0.779), which ruled out the potential for any non-response bias.

Of the respondents that indicated their position, $85.0 \%$ reported they were a pharmacy owner-manager, a store manager, or a director of pharmacy. Most of the remaining $15 \%$ respondents reported that they were staff pharmacists. Overall the group of respondents was believed to be informed about the entrepreneurial activities of their pharmacies, based on their position. The mean score on the involvement scale was 3.9 on a five-point scale indicating that they were both qualified and involved with the strategies of the store.

The alphas for the six scales, reported in Appendix, ranged from 0.82 (MOTIVATION) to 0.92 (RISK TAKING) and are above the lower limits of acceptability, generally considered to be around 0.60 (Nunnally, 1978) for the newly developed scales. Finally, the scores for each scale were determined by adding up the individual scores for the corresponding measures and then dividing by the number of measures. The factor loadings, eigen values and variance explained are shown in Table1. 
Insert Table 1 about here

The reliability (coefficient alpha) of the measures for the environmental and organizational factors was competitive intensity (0.90), munificence (0.86), stability (0.63), organicity (0.85), adaptability (0.87), and tolerance for ambiguity (0.76). The factor loadings, Eigen values and variance explained for environmental factors and organizational factors are shown in Tables $2 \& 3$.

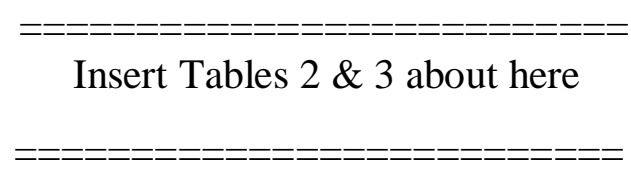

The reliability coefficients for the performance scales, effectiveness and customer orientation were 0.86 and 0.65 respectively. The factor analysis for the performance measures resulted in multiple factors, with the highest factor loadings spread across the factors.

The six-cluster model best met the stated criteria. The null hypothesis that the six clusters are equal across all defining variables was rejected at the 0.0001 level of significance. Table 4 presents the cluster means, the standard errors, the group numbers from which this group was significantly different at the 0.05 level of significance or less, and the relative ranking of the entrepreneurial characteristics within each group. The F-statistics indicate strong evidence that one or more of the cluster means differed from another on all six defining variables, at the 0.0001 level of significance. Further, the Tukey HSD pairwise comparisons of the mean difference, at the 0.05 level of significance or less, indicated that $44 \%$ of the group means were different from all of the other five group means, $28 \%$ were different from four of the five groups, and $28 \%$ were different from three or less.

Insert Table 4 about here

The six clusters are named: Competitive Aggressors (Cluster 1), Ambitious (Cluster 2); True Entrepreneurs (Cluster 3), Low-Risk Entrepreneurs (Cluster 4), Proactive Innovators 
(Cluster 5), and Anything but Entrepreneurs (Cluster 6). The interpretation of the groups is based on whether (a) the combination of intangible resources varies significantly among clusters, and (b) the relative emphasis of a particular intangible resource is significantly different from other intangible resources combined within a cluster.

\section{Cluster 1: Competitive Aggressors.}

This cluster of thirty-one pharmacy units ascribes significantly higher emphasis to competitive aggressiveness compared to three other clusters - Cluster \#2 (Ambitious), \#5 (Proactive Innovators), and \#6 (Anything but Entrepreneurs). Proactiveness and Innovativeness are both rated significantly below the preference given by the members of clusters 3,4 and 5 . Cluster 1 organizations’ risk-taking propensity is rated significantly lower than in clusters \#3 and \#5, and autonomy and motivation are significantly lower than in clusters \# 3 and \#4. This cluster is named "Competitive Aggressors" for their high emphasis on competitive aggressiveness compared to most other entrepreneurial characteristics within this cluster. The pharmacies in this group appear to be emphasizing competitive aggressiveness so as to challenge their competitors to improve their market position. The Competitive Aggressors are the fourth largest group, representing 13 percent of the cases in six clusters.

\section{Cluster 2: Ambitious.}

This cluster of 23 units distinguishes itself from the Competitive Aggressors (cluster 1), based on a significantly lower emphasis on competitive aggressiveness, proactiveness and autonomy. The top priority within this cluster is motivation with a score of 6.06, which is significantly higher than that of Cluster \#6 and not significantly lower than any other cluster. Further, within this cluster, the emphasis on motivation is significantly higher (2 to 3 times) than that on any other characteristic, that is why the name - Ambitious. The Ambitious group is the second smallest group, representing about nine percent of the cases. 


\section{Cluster 3: True Entrepreneurs.}

This group’s organizations emphasize risk-taking, proactiveness and innovativeness to a greater extent than all other clusters. Their emphasis on autonomy and competitive aggressiveness is significantly higher than four of the five clusters, but not significantly lower than the members of cluster 4. The True Entrepreneurs are the largest group accounting for 30\% percent of the cases. This cluster of 76 units places a simultaneously high emphasis on all six entrepreneurial characteristics. This group’s emphasis on all six characteristics exceeds 5.3, which earns this group the name - True Entrepreneurs.

\section{Cluster 4: Low-Risk Entrepreneurs.}

This cluster of thirty-seven units, representing about $14 \%$ of the cases in all six groups, is very similar to Cluster \#3 (True Entrepreneurs) with one exception - a significantly lower emphasis on risk taking. Like Cluster \#3, this group is significantly higher than the other four groups on proactiveness, innovativeness, and autonomy. On competitive aggressiveness and motivation, it is significantly higher than three of the four groups but not significantly lower than Cluster \#3, True Entrepreneurs. This group has significantly lower emphasis on risk-taking (about a one-half or one-third) compared to all other characteristics within the cluster. Thus, it is named - Low-Risk Entrepreneurs.

\section{Cluster 5: Proactive Innovators.}

This cluster of 71 pharmacies rates significantly higher on proactiveness and innovativeness compared to clusters 1,2 and 6 . The emphasis on motivation, though ranked high within this group, is not significantly different than the Ambitious group. The emphasis on proactiveness and innovativeness, however, ranks among the top characteristics within the group, which earns this group the name, Proactive Innovators. 


\section{Cluster 6: Anything but Entrepreneurs.}

This relatively small group of thirteen pharmacies rates significantly lower than all of the other five groups on proactiveness, innovativeness, autonomy, and motivation. Compared to the True Entrepreneurs group, this group’s emphasis on all six of the entrepreneurial characteristics is about one-half to a one-third. That is why the name Anything but Entrepreneurs.

The above results support Hypothesis 1 and suggest that in general, pharmacies emphasize various sets of intangible resources that reflect their strategies to stay ahead of the competition within their industry. Based on their willingness and ability to be innovative, proactive, autonomous, competitive aggressive, risk taking, and motivating, we were able to classify various pharmacies into six groups.

\section{Traditional Pharmacy Types by Cluster}

Table 5 illustrates the distribution of the six groups by traditional pharmacy type in the sample. Even though a significant chi-square test suggests that there are discernible patterns in the relationship between cluster membership and pharmacy type, we found that each cluster had representation from all different types of pharmacies with one exception. That is, the outpatient hospital pharmacies are not represented in the Anything-but-Entrepreneurs group. Otherwise, in the six clusters, there are multiple competitors in each type of pharmacy with some noteworthy patterns discussed next.

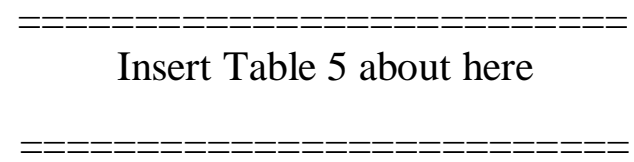

Forty-three percent of Independents are True Entrepreneurs and twenty-nine percent are Proactive Innovators. A similar pattern is observed for Small chains as well, with 30\% small chains being True Entrepreneurs and an equal number being the Proactive Innovators. Large chains seem to be all over the place, with nearly 20 percent in each of the following clusters: Competitive Aggressors, True Entrepreneurs, No-risk entrepreneurs, and Proactive Innovators. 
A considerable proportion (28\%) of Food-Drug Combos is Proactive Innovators, followed by 19\% each in the Competitive Aggressors and the Anything but Entrepreneurs cluster.

It is interesting to note that $41 \%$ of Mass Merchandisers in the sample are True Entrepreneurs, which surprisingly parallels the Independents $-43 \%$ of Independents are true entrepreneurs. This finding runs contrary to the popular notion that would suggest only Independents and Small chains to be True Entrepreneurs. It is also worth noting that about a half of all Outpatient Hospital pharmacies in the sample are Proactive Innovators, and about a onethird are True Entrepreneurs.

Over one-third of all Competitive Aggressors are large chains, followed by Independents (23\%) and Food \& Drug stores (19\%). Also, about a one-third of the membership in the Ambitious group is from Large Chains followed by 22\% each from Independents and Food \& Drug Combos. A significant proportion, about 60\%, of True Entrepreneurs comes from Independents, followed by $13 \%$ from Large Chains. Forty percent of Low-Risk Entrepreneurs are also Independents followed by 31\% Large Chains. Forty-five percent of Proactive Innovators are Independents and $46 \%$ of the membership in the Anything but Entrepreneurs group is from Food \& Drug Combos.

While some broad patterns of pharmacy types appear within cluster group membership, a more detailed examination shows that competitors within a pharmacy type (independents, large chains) belong to different clusters. That is, as stated in Hypothesis 2, the taxonomy based on intangible resources is different than the traditional taxonomy for retail pharmacies. A wide spread of pharmacies across different clusters suggests that the same type of pharmacies (e.g., large chain pharmacies) use different combinations of intangible resources to compete. This is consistent with Porter's (1980) views that a broad range of strategies is available to competitors within an industry. 


\section{Cluster-Orientation and Perception of the Environmental and Organizational Factors}

Table 6 presents the cluster mean scores and the standard errors of the three environmental factors and three organizational factors. One or more of the six clusters are significantly different from another on their perception of all three dimensions of their environments - Munificence ( $\mathrm{F}=13.97, \mathrm{p}<0.0001)$, Competitive Intensity $(\mathrm{F}=2.39, \mathrm{p}<0.05)$, and Environmental Stability ( $\mathrm{F}=3.35, \mathrm{p}<0.01)$. These results support Hypothesis 3. Similarly, significant variation was found for the three organizational factors: Organicity $(\mathrm{F}=6.31, \mathrm{p}$ $<0.0001)$, Adaptability ( $\mathrm{F}=48.65, \mathrm{p}<0.0001)$, and Tolerance for Ambiguity $(\mathrm{F}=3.19, \mathrm{p}<0.01)$.

These results support Hypotheses 4. The results supporting Hypothesis 3 and 4 are discussed in detail in the following paragraphs.

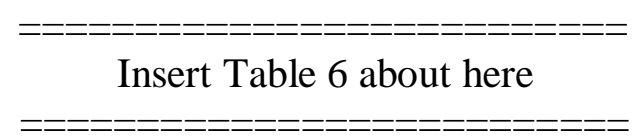

The True Entrepreneurs and Low-Risk Entrepreneurs perceive the growth opportunities (Munificence) more readily than the other four groups. Consistent with the name, the Anything but Entrepreneurs group's perception of munificence is significantly lower than the rest. All groups rate the competition in the industry to be intense (Competitive Intensity), with Low-Risk Entrepreneurs topping the list, followed by Anything but Entrepreneurs. The perception of the competitive intensity is significantly higher for the Low-Risk Entrepreneurs group than those of Proactive Innovators and the Ambitious group. All groups seem to rate the predictability of the business environment (Environment Stability) to be low or medium, with Anything but Entrepreneurs and the Ambitious groups rating their environments the least predictable.

As expected, the True Entrepreneurs and Proactive Innovators appear to maintain a significantly less formal control of employees based on rules and regulations (Organicity) as compared to at least two of the five groups. Also, Competitive Aggressors are more formalized and rigid compared to the other groups, and significantly so from the True Entrepreneurs group. As expected, the two Entrepreneurs - True and Low-Risk - are the most willing and able to change (Adaptability) followed by Competitive Aggressors and Proactive Innovators. Further, 
consistent with expectations, Anything but Entrepreneurs are the least adaptable group. The True Entrepreneurs and the Proactive Innovators have significantly higher tolerance for ambiguity compared to the Low-Risk Entrepreneurs and the Ambitious group.

\section{Performance Differences Across Clusters}

Table 7 presents the cluster comparisons on each of the six performance measures. Supporting Hypothesis 5, one or more of the six clusters are significantly different from another, at $\mathrm{p}<0.01$ level or less, on all four performance measures - Effectiveness $(\mathrm{F}=16.85, \mathrm{p}<$ 0.0001), Customer Orientation ( $\mathrm{F}=21.71, \mathrm{p}<0.0001)$, Growth $(\mathrm{F}=3.74, \mathrm{p}<0.01)$, and the number of Innovative Services provided $(\mathrm{F}=6.78, \mathrm{p}<0.0001)$.

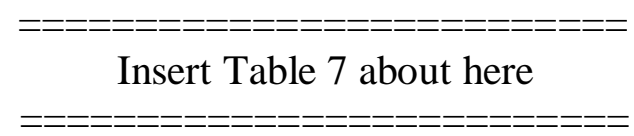

The True Entrepreneurs (Cluster \#3) and the Low-Risk Entrepreneurs (Cluster \#4) are significantly more effective and more customer-oriented than the other four clusters. Based on a within cluster analysis, all six groups, however, seem to rate their customer orientation higher than their effectiveness.

The True Entrepreneurs also perceive their growth to be significantly faster than their competitors, especially the Proactive Innovators and the Anything but Entrepreneurs groups. The other three groups - Competitive Aggressors, Ambitious, and the Low-Risk Entrepreneurs perceive their growth to be similar to their competitors.

The two groups of Entrepreneurs - True and Low-Risk - offer significantly higher number of innovative services as compared to three other groups - Competitive Aggressors, Ambitious, and Anything but Entrepreneurs. The Proactive Innovators group with an average of 
4.28 innovative services provided ranks third, and is significantly higher in their offerings as compared to the Ambitious group.

\section{CONCLUSIONS}

This study utilized concepts from Resource-Advantage Theory to develop a taxonomy for service providers based on the pharmacies' ability to gather and use combinations of entrepreneurial activities such as innovativeness, proactiveness, risk-taking, motivation, autonomy, and competitive aggressiveness. Analysis revealed that the resultant six groups of pharmacies, regardless of their traditional "type" classification, adopted different mixes of entrepreneurial orientation as intangible resources. An organization's emphasis on these resources is indicative of its strategies to develop and sustain a competitive advantage in the long run. Further, organizations across these six groups seem to perceive the growth opportunities, competition within the industry, and environmental stability differently. The resultant groups also seem to perform better on measures consistent with their entrepreneurial orientation.

For example, Competitive Aggressors, $13 \%$ of the sample, ascribe significantly higher emphasis to challenging their competitors to improve their own market position. The Ambitious group of pharmacies, with nine percent of the respondents, places a high emphasis on enhancing

its employees' attitude and morality toward work. Favorable attitudes toward and moral belief in hard work are expected to contribute to employees' motivation toward achieving strategic goals of the company. Their effectiveness in meeting organizational performance objectives and goals is better or equal to three other groups in the industry.

The second biggest cluster (71 Proactive-Innovator pharmacies), 28\% of the sample, gives significantly high importance to anticipating and acting on future needs. Such proactive 
behavior helps them engage in and support new ideas, novelty experimentation, and creative processes before their competitors. Their perception of industry-related environmental stability is quite low. Consistent with their orientation, they seem to proactively seek out what their customers want and provide services that meet customers' needs. No wonder, their performance on customer orientation and the number of innovative services provided is better or equal to three of the other five groups in the industry.

The biggest group, 76 True Entrepreneurs, represented 30\% of the sample. Organizations of this type place a simultaneously high emphasis on all six entrepreneurial characteristics, which is in excess of 5.3 on a scale of 1-7. This group perceives high growth opportunities in the industry and goes all out to exploit it to stay ahead of the competitors. This is evidenced through their significantly high performance on customer orientation, which means that their success comes from meeting their customers' needs. Consistent with their entrepreneurial orientation, they also offer the highest number of innovative services.

The Low-Risk Entrepreneurs, $15 \%$ of the sample, is very similar to the True Entrepreneurs, but with a significantly low risk propensity. Consistent with their orientation, they perceive the competition in the industry to be extreme and have a relatively low tolerance for ambiguity. These organizations have oriented their strategy toward innovation, but are unwilling or unable to take the risks associated with full entrepreneurship. This approach, given their environments, makes them significantly more effective in consistently meeting their organizational performance goals and objectives as compared to their competitors in the industry. Consistent with their entrepreneurial spirit, they provide significantly higher number of innovative services compared to three other groups, but not significantly lower than their counterparts in the True Entrepreneurs and the Proactive Innovators groups. 
The smallest group, with five percent of the respondents, was the Anything but Entrepreneurs. Nearly half the pharmacies in this group are the Food \& Drug Combination stores, also known as the supermarket pharmacies. Their perception of the competition in the industry is quite high, yet they seem to do nothing about it in terms of developing strategies to counter that. Consistently they are least effective in meeting their performance objectives, are less oriented to meeting their customers' needs, and provide the least number of innovative pharmacy services.

Our taxonomy is consistent with the strategic typology proposed by Miles and Snow (1978) in some ways. On the degree of innovativeness, proactiveness, and risk propensity, our True Entrepreneurs would parallel their Prospectors. Both also possess the characteristics of adaptability and favor an organic structure. Our Anything but Entrepreneurs group could be viewed as their Defenders, both are the least adaptable and favor a mechanistic structure. Their Analyzers would be our risk minimizers, the groups of Low-risk Entrepreneurs, Ambitious, and Competitive Aggressors. Although we developed an empirical taxonomy within a service industry and Miles and Snow developed a general typology applicable across industries, there are similarities as noted above. Also, their typology was based on the then existing literature and studies in four service industries, including health care.

\section{IMPLICATIONS, LIMITATIONS AND FUTURE RESEARCH}

This paper developed a classification scheme for grouping competitors within one service industry based on an organization's ability to develop and utilize intangible resources for strategic entrepreneurial activities. The measures used in this study (innovativeness, proactiveness, risk taking, motivation, autonomy and competitive aggressiveness) could be used 
by researchers to develop similar taxonomies in other service industries. This classification seems superior to the traditional classification of pharmacies that is mainly based on the number of stores and type of operation. The traditional way of classifying pharmacies assumes all independent pharmacies to be more entrepreneurial and all mass merchandisers or large chains as less entrepreneurial. The use of entrepreneurial orientation as a construct to classify pharmacies could also serve as a useful tool to classify firms in other industries. These concepts represent intangible resources that can be used by many service organizations to create a competitive advantage in their markets.

Future research should investigate how different combinations of intangible resources (e.g. entrepreneurial orientation) can facilitate the development of new services. The pharmacy industry involves both goods and services in their offerings. It is unclear whether combinations of intangible resources similar to those reported here would exist for industries that are more purely service providers. In addition, a taxonomy that combines tangible and intangible resources could provide useful distinctions among organizations in an industry.

The intangible resources were used to identify strategic groups within an industry. These groups differed in combinations of intangible resources related to entrepreneurial activities, environments, organizational characteristics and performance. We are able to show that the proposed taxonomy provides a better way of grouping pharmacies based on their entrepreneurial orientation as compared to the traditional scheme of classifying them as Independents, Chains, Mass Merchandisers, etc., based on the number of stores and type of merchandise sold. Further, under the traditional classification scheme one could find a successful and good performing pharmacy in any group, whereas the proposed taxonomy unraveled that if a pharmacy is identified with a group based on its entrepreneurial orientation as an intangible resource, it is 
expected to perform better on certain performance criteria consistent with its orientation. Given the extent of mergers and acquisitions in the retail pharmacy industry, this taxonomy could be helpful to practitioners in making such takeover decisions.

From research perspective, we were able to take the service classification research from a macro level to the micro level by focusing on one industry - the retail pharmacy industry. Thus, instead of classifying an entire industry as one type, as has been often done in the service literature, the proposed taxonomy demonstrates how intangible resources could be used to classify organizations within an industry. Managers and researchers are encouraged to utilize such a taxonomy for other industries. 


\section{REFERENCES}

Achrol, A.S., and L.W. Stern (1988), "Environmental Determinants of Decision-Making Uncertainty in Marketing Channels," Journal of Market Research, 25(2), 36-50.

Aldenderfer, M.S., and R.K. Blashfield (1984), Cluster Analysis, Sage: London.

Barney, J.B (1991), "Firm Resources and Sustained Competitive Advantage," Journal of Management, 17(3), 99-120.

Bourgeois, L.J. (1981), "On the Measurement of Organizational Slack," Academy of Management Review, 6(1), 629-39.

Boyer, K.K., C. Bozarth, and C. McDermott (2000), "Configurations in Operations: An Emerging Area of Study," Journal of Operations Management, 18(6), 601-604.

Boyer, K.K., P.T. Ward, and G.K. Leong (1996), "Approaches to the Factory of the Future: An Empirical Taxonomy," Journal of Operations Management, 14, 297-313.

Chakravarthy, B (1982), "Adaptation: A Promising Metaphor for Strategic Management," Academy of Management Review, 7(1), 735-744.

Chase, R.B (1978), "Where Does the Customer Fit in a Service Operation?," Harvard Business Review, 56(6), 137-142.

Chase, R.B (1996), "The Mall is My Factory: Reflections of a Service Junkie," Productions and Operations Management, 5(4), 298-308.

Consumer reports (1999), The ABCs of Drug Stores, October, 39-44.

Cook, D.P., C.H. Goh, and C.H. Chung (1999), "Service Typologies: A State of the Art Survey," Production and Operations Management, 8(3), 318-338.

Covin, J.G., and D.P. Slevin (1989), "Strategic Management of Small Firms in Hostile and Benign Environments," Strategic Management Journal, 10(1), 1075-1087.

Covin, J.G., and D.P. Slevin (1991), "A Conceptual Model of Entrepreneurship as Firm Behavior," Entrepreneurship: Theory and Practice/Entrepreneurship: Theory and Practice, 16(1), 7-24.

Cyert, R.M., and J.G March (1963), "A Behavioral Theory of the Firm" Englewood Cliffs, New Jersey: Prentice Hall, Inc.

Dess, G.G., and D.W Beard (1984), "Dimensions of Organizational Task Environments," Administrative Science Quarterly, 29(3), 52-73.

Doucette, W.R., J.C Schommer, and J.B. Wiederholt (1993.), "The Political Economy of 
Pharmaceutical Marketing Channels: A Conceptual Framework," Clin Therapeutics, 15(4), 739-751.

Duncan, R.B. (1972), "Characteristics of Organizational Environments and Perceived Uncertainty," Administrative Science Quarterly, 17(9), 313-327.

Flynn, B.B., S. Sakakibara, R.G. Schroeder, K.A. Bates, and E.J. Flynn (1990), "Empirical Research Methods in Operations Management," Journal of Operations Management, 9(2), 250-284.

Frohlich, M.T., and J.R. Dixon (2001), "A Taxonomy of Manufacturing Strategies Revisited," Journal of Operations Management, 19(5), 541-558.

Gasse, Y. (1982), "Elaborations on the Psychology of the Entrepreneur," Encyclopedia of Entrepreneurship, 209-223.

Giffi, C., A.V. Roth, and G. Seal (1990), "Competing in World Class Manufacturing: America's 21st Century Challenge”, Homewood, IL: Business One Irwin.

Haywood-Farmer, J (1988), "A Conceptual Model of Service Quality," International Journal of Operations \& Production Management, 8(6), 19-29.

Huete, L.M. and A.V. Roth (1988), "The Industrialization and Span of Retail Banks’ Delivery Systems," International Journal of Operations \& Production Management, 8(3), 46-66.

Hunt, S.D., and R.M. Morgan (1995), "The Comparative Advantage Theory of Competition," Journal of Marketing, 59(2), 1-15.

Hunt, S.D., and R.M. Morgan (1996), "The Resource-Advantage Theory of Competition: Dynamics, Path Dependencies, and Evolutionary Dimensions," Journal of Marketing, 60(3), 107-114.

Kathuria, R (2000), "Competitive Priorities and Managerial Performance: A Taxonomy of Small Manufacturers," Journal of Operations Management, 18(6), 627-641.

Kellogg, D.L. and W. Nie (1995), "A Framework for Strategic Service Management," Journal of Operations Management, 13(4), 323-338.

Khandwalla, P (1987), "Generators of Pioneering Innovative Management: Some Indian Evidence," Organizational Studies, 8(1), 39-59.

Lehmann, D.R (1979), "Market Research and Analysis," Irwin, Homewood, IL.

Lovelock, C.H. (1983), "Classifying Services to Gain Strategic Marketing Insights," Journal of Marketing, 47(3), 9-20. 
Lumpkin, G.T., and G.G. Dess (1996), "Clarifying the Entrepreneurial Orientation Construct and Linking it to Performance," Academy of Management Review, 21(1), 135-172.

Lumpkin, G.T., and G.G. Dess (2001), "Linking two dimensions of entrepreneurial orientation to firm performance: The moderating role of environment and industry life cycle," Journal of Business Venturing, 16(5), 429-451.

Menor, L.J., A.V. Roth, and C.H. Mason (2002), "Agility in Retail Banking : A Numerical Taxonomy of Strategic Service Groups," Manufacturing \& Service Operations Management, 3(4), 273-292.

Metters, R. and V. Vergas (2000), "A Typology of De-Coupling Strategies in Mixed Services," Journal of Operations Management, 18(6), 663-682.

Miles, R.E., Snow, C.C., Meyer, A.D., and Coleman, H.J. Jr. (1978), “Organizational Strategy, Structure and Process,” Academy of Management Review, 3(3), 546-562.

Miller, D (1983), "The Correlates of Entrepreneurship in Three Types of Firms," Management Science, 29(7), 770-791.

Miller, D. and, P. Friesen (1978), "Archetypes of Strategy Formulation," Management Science, 24(9), 921-933.

Miller, D., and P. Friesen (1982), "Innovation in Conservative and Entrepreneurial Firms: Two Models of Strategic Momentum," Strategic Management Journal, 3(1), 1-25.

Miller, J.G., and A.V. Roth (1994), "A Taxonomy of Manufacturing Strategies," Management Science, 40(3), 285-304.

National Association of Chain Drug Stores, "Community Retail Pharmacy Outlets by Type of Store, 1991-2002,” http://www.nacds.org/user-assets/PDF files/Retail_Outlets.pdf, Accessed 02-032004.

NDC Health (2002), "Pharma Trends 2001 Year in Review," NDC Pharmaceutical Audit Suit, Atlanta, GA.

Noble, M.A (1995), "Manufacturing Strategy: Testing the Cumulative Model in a Multiple Country Context," Decision Sciences, 26(5), 693-721.

Nunnally, J. D (1978), "Psychometric Theory, (2nd Ed.)," New York, NY: McGraw-Hill.

N.W.D.A. (2000), U.S. Health Care Financing Administration, Office of the Actuary National Health Expenditures and Selected Economic Indicators, Levels and Average Annual Percent Change Selected Calendar Years 1970-2008.

Pfeffer, J., and G.R. Salancik (1978), "The External Control of Organizations," New York: Harper and Row. 
Porter, M (1980), "Competitive Strategy: Techniques for Analyzing Industries and Competitors, " New York: Free Press.

Priem, R. L., and J.E. Butler (2001), "Is the Resource-Based View a Useful Perspective for Strategic Management Research ?," Academy of Management Review, 26(1), 22-40.

Richardson, P.R., A.J. Taylor, and R.M. Gorden (1985), "A Strategic Approach to Evaluating Manufacturing Performance," Interfaces, 15(6), 15-27.

Roth, A.V., and W.J. Jackson (1995), "Strategic Detriments of Service Quality and Performance," Management Science, 41(11), 1720-1733.

Schmenner, R.W (1986), "How Can Service Businesses Survive and Prosper?," Sloan Management Review, 27(3), 21-32.

Silvestro, R., L. Fitzgerald, R. Johnston, and C. Voss (1992), "Towards a Classification of Service Processes," International Journal of Service Industries Management, 3(3), 6275.

Starbuck, W.H (1976), "Organizations and their environments," In Handbook of Industrial and Organizational Psychology, 1069-1123.

Swamidass, P.M. (1991), "Empirical Science: New Frontier in Operations Management Research," Academy of Management Review, 16(4), 793-814.

Venkatraman, N (1989), "Strategic Orientation of Business Enterprises: The Construct, Dimensionality, and Measurement," Management Science, 35(8), 942-962.

Venkatraman, N., and V. Ramanujam (1987), "Measurement of Business Economic Performance: An Examination of Method Convergence," Journal of Management, 13(1), 109-122.

Verma R, G.M. Thompson, and J.J. Louviere (1999), "Configuring Service Operations in Accordance With Customer Needs and Preferences," Journal of Service Research, 1(3), 262-274.

Verma, R. and K.K. Boyer (2000), "Service Classifications and Management Challenges," Journal of Business Strategies, 17(1), 5-24.

Verma, R. and S.T. Young (2000), "Configurations of Low-contact Services," Journal of Operations Management, 18(6), 643-661.

Ward, P., G.K. Duray, G.K. Leong, and C. Sum (1995), "Business Environment, Operations Strategy, and Performance: An Empirical Study of Singapore Manufacturers," Journal of Operations Management, 13(2), 99-115. 
Table 1: Factor Loadings of Dimensions of Entrepreneurial Orientation

\begin{tabular}{|c|c|c|c|c|c|c|}
\hline Item $^{1}$ & $\begin{array}{l}\text { Factor } 1 \\
\text { Risk } \\
\text { Taking } \\
\end{array}$ & $\begin{array}{l}\text { Factor } 2 \\
\text { Innovation }\end{array}$ & $\begin{array}{l}\text { Factor } 3 \\
\text { Motivation }\end{array}$ & $\begin{array}{l}\text { Factor } 4 \\
\text { Proactiveness }\end{array}$ & $\begin{array}{l}\text { Factor } 5 \\
\text { Competitive } \\
\text { Aggressiveness }\end{array}$ & $\begin{array}{l}\text { Factor } 6 \\
\text { Autonomy }\end{array}$ \\
\hline RISK1 & .839 & .193 & -.011 & .100 & -0.023 & .125 \\
\hline RISK2 & .879 & .114 & .092 & .149 & .090 & .118 \\
\hline RISK3 & .887 & .187 & .044 & .079 & .125 & .006 \\
\hline RISK4 & .867 & .185 & .060 & .176 & .103 & .047 \\
\hline INNOV1 & .292 & .720 & .255 & .207 & .109 & .188 \\
\hline INNOV2 & .194 & .814 & .188 & .290 & .150 & .093 \\
\hline INNOV3 & .200 & .819 & .236 & .261 & .118 & .123 \\
\hline INNOV4 & .412 & .600 & .164 & .290 & .153 & .137 \\
\hline MOTIV1 & .118 & .261 & .768 & .158 & .159 & .134 \\
\hline MOTIV2 & -.006 & .102 & .846 & .170 & .102 & .037 \\
\hline MOTIV3 & .045 & .235 & .812 & .184 & .171 & .165 \\
\hline MOTIV4 & .216 & .329 & .492 & .372 & .302 & .105 \\
\hline PROACT1 & .375 & .366 & .128 & .547 & .275 & .067 \\
\hline PROACT2 & .146 & .329 & .257 & .549 & .416 & .073 \\
\hline PROACT3 & .182 & .400 & .180 & .662 & .313 & .160 \\
\hline PROACT4 & .193 & .358 & .285 & .499 & .372 & .234 \\
\hline COMPAG1 & -.075 & .087 & .155 & .333 & .735 & -.106 \\
\hline COMPAG2 & .145 & .089 & .119 & .087 & .813 & .095 \\
\hline COMPAG3 & .089 & .020 & .093 & .289 & .730 & .282 \\
\hline COMPAG4 & .132 & .251 & .121 & .001 & .795 & .278 \\
\hline AUTON1 & .248 & .226 & .236 & .414 & .085 & .653 \\
\hline AUTON2 & .117 & .241 & .187 & .363 & .135 & .720 \\
\hline AUTON3 & .174 & .138 & .099 & .243 & .197 & .813 \\
\hline AUTON4 & .046 & .222 & .244 & .299 & .262 & .617 \\
\hline Eigen Value & 10.846 & 2.722 & 1.018 & 1.717 & 1.162 & 1.001 \\
\hline $\begin{array}{l}\text { Variance } \\
\text { Explained }\end{array}$ & 15.802 & 14.002 & 11.323 & 13.590 & 13.533 & 7.417 \\
\hline
\end{tabular}

${ }^{1}$ The Item Abbreviations correspond to Items shown in the Appendix 
Table 2: Factor Loadings of Environmental Variables

\begin{tabular}{|l|l|l|l|}
\hline \multicolumn{1}{|c|}{ Item $^{1}$} & $\begin{array}{l}\text { Factor 1 } \\
\text { Munificence }\end{array}$ & $\begin{array}{l}\text { Factor 2 } \\
\text { Competitive } \\
\text { Intensity }\end{array}$ & $\begin{array}{l}\text { Factor 3 } \\
\text { Stability }\end{array}$ \\
\hline MUNIF1 & $\mathbf{. 8 2 5}$ & .028 & .083 \\
\hline MUNIF2 & $\mathbf{. 7 5 0}$ & .044 & .216 \\
\hline MUNIF3 & $\mathbf{. 8 6 5}$ & .022 & .144 \\
\hline MUNIF4 & $\mathbf{. 8 4 7}$ & .029 & .201 \\
\hline COMPIN1 & .045 & $\mathbf{. 8 7 3}$ & .055 \\
\hline COMPIN2 & .105 & $\mathbf{. 8 8 9}$ & .073 \\
\hline COMPIN3 & .028 & $\mathbf{. 9 1 3}$ & .0001 \\
\hline COMPIN4 & -.043 & $\mathbf{. 8 2 3}$ & .074 \\
\hline DYNAM1 & .338 & .239 & $\mathbf{. 5 1 2}$ \\
\hline DYNAM2 & -.155 & .024 & $\mathbf{. 6 8 3}$ \\
\hline DYNAM3 & .213 & -.0026 & $\mathbf{. 5 9 8}$ \\
\hline DYNAM4 & .140 & .071 & $\mathbf{. 4 8 1}$ \\
\hline DYNAM5 & .355 & -.050 & $\mathbf{. 6 8 9}$ \\
\hline & & & \\
\hline Eigen Value & 2.646 & 4.162 & 1.819 \\
\hline Variance Explained & 20.851 & 25.761 & 19.750 \\
\hline
\end{tabular}

${ }^{1}$ The Item Abbreviations correspond to Items shown in the Appendix

Table 3: Factor Loadings of Organizational Variables

\begin{tabular}{|l|l|l|l|}
\hline \multicolumn{1}{|c|}{ Item $^{1}$} & $\begin{array}{l}\text { Factor 1 } \\
\text { Adaptability }\end{array}$ & $\begin{array}{l}\text { Factor 2 } \\
\text { Tolerance to Ambiguity }\end{array}$ & $\begin{array}{l}\text { Factor 3 } \\
\text { Organicity }\end{array}$ \\
\hline ADAPT1 & $\mathbf{. 8 0 1}$ & -.066 & .172 \\
\hline ADAPT2 & $\mathbf{. 8 6 3}$ & -.105 & .105 \\
\hline ADAPT3 & $\mathbf{. 8 9 1}$ & -.060 & .129 \\
\hline TOLAMB1 & .368 & $\mathbf{. 5 2 4}$ & .271 \\
\hline TOLAMB2 & -.104 & $\mathbf{. 8 4 9}$ & -.020 \\
\hline TOLAMB3 & .028 & $\mathbf{. 8 9 6}$ & .053 \\
\hline TOLAMB4 & -.066 & $\mathbf{. 9 2 6}$ & .005 \\
\hline ORGSTR1 & .131 & .045 & $\mathbf{. 8 2 1}$ \\
\hline ORGSTR2 & .011 & .076 & $\mathbf{. 8 5 4}$ \\
\hline ORGSTR3 & .003 & .082 & $\mathbf{. 8 3 4}$ \\
\hline & & & 3.902 \\
\hline Eigen Value & 2.915 & 1.294 & 24.109 \\
\hline Variance Explained & 23.496 & 14.790 & \\
\hline
\end{tabular}

${ }^{1}$ The Item Abbreviations correspond to Items shown in the Appendix 
Table 4: Entrepreneurial Characteristics by Clusters

\begin{tabular}{|c|c|c|c|c|c|c|c|}
\hline $\begin{array}{l}\text { Entrepreneurial } \\
\text { characteristics }\end{array}$ & $\begin{array}{l}\text { Competitive } \\
\text { Aggressors } \\
\mathrm{n}=31 \\
\text { Cluster \#1 }\end{array}$ & $\begin{array}{l}\text { Ambitious } \\
\mathrm{n}=23 \\
\text { Cluster \#2 }\end{array}$ & $\begin{array}{l}\text { True } \\
\text { Entrepreneurs } \\
n=76 \\
\text { Cluster \#3 }\end{array}$ & $\begin{array}{l}\text { Low-risk } \\
\text { Entrepreneurs } \\
n=37 \\
\text { Cluster \#4 }\end{array}$ & $\begin{array}{l}\text { Proactive } \\
\text { Innovators } \\
\mathrm{n}=71 \\
\text { Cluster \#5 }\end{array}$ & $\begin{array}{l}\text { Anything but } \\
\text { Entrepreneurs } \\
\mathrm{n}=13 \\
\text { Cluster \#6 }\end{array}$ & $\begin{array}{l}F=\text { Value } \\
(p=\text { probability })\end{array}$ \\
\hline $\begin{array}{l}\text { Risk taking } \\
\text { Cluster Mean } \\
\text { Std. error } \\
\text { Rank }\end{array}$ & $\begin{array}{l}2.71(3,5) \\
.14 \\
6\end{array}$ & $\begin{array}{l}2.09(3,5) \\
.18 \\
6\end{array}$ & $\begin{array}{l}5.39(1,2,4,5,6) \\
.11 \\
5\end{array}$ & $\begin{array}{l}2.15(3,5) \\
.15 \\
6\end{array}$ & $\begin{array}{l}4.70(1,2,3,4,6) \\
.09 \\
4\end{array}$ & $\begin{array}{l}2.05(3,5) \\
.33 \\
3\end{array}$ & $\begin{array}{l}F=126.11 \\
p<.0001\end{array}$ \\
\hline $\begin{array}{l}\text { Proactiveness } \\
\text { Cluster Mean } \\
\text { Std. error } \\
\text { Rank }\end{array}$ & $\begin{array}{l}4.56(2,3,4,5,6) \\
.13 \\
4\end{array}$ & $\begin{array}{l}3.37(1,3,4,5,6) \\
.22 \\
4\end{array}$ & $\begin{array}{l}6.22(1,2,4,5,6) \\
.07 \\
2\end{array}$ & $\begin{array}{l}5.78(1,2,3,5,6) \\
.11 \\
2\end{array}$ & $\begin{array}{l}5.00(1,2,3,4,6) \\
.07 \\
2\end{array}$ & $\begin{array}{l}2.07(1,2,3,4,5) \\
.25 \\
2\end{array}$ & $\begin{array}{l}F=127.27 \\
p<.0001\end{array}$ \\
\hline $\begin{array}{l}\text { Innovativeness } \\
\text { Cluster Mean } \\
\text { Std. error } \\
\text { Rank }\end{array}$ & $\begin{array}{l}3.19(3,4,5,6) \\
.17 \\
5\end{array}$ & $\begin{array}{l}3.46(3,4,5,6) \\
.22 \\
2\end{array}$ & $\begin{array}{l}6.06(1,2,4,5,6) \\
.08 \\
3\end{array}$ & $\begin{array}{l}5.56(1,2,3,5,6) \\
.12 \\
3\end{array}$ & $\begin{array}{l}4.81(1,2,3,4,6) \\
.10 \\
3\end{array}$ & $\begin{array}{l}1.64(1,2,3,4,5) \\
.27 \\
6\end{array}$ & $\begin{array}{l}F=107.74 \\
p<.0001\end{array}$ \\
\hline $\begin{array}{l}\text { Autonomy } \\
\text { Cluster Mean } \\
\text { Std. error } \\
\text { Rank }\end{array}$ & $\begin{array}{l}4.57(2,3,4,6) \\
.14 \\
3\end{array}$ & $\begin{array}{l}3.40(1,3,4,5,6) \\
.24 \\
3\end{array}$ & $\begin{array}{l}5.75(1,2,5,6) \\
.10 \\
4\end{array}$ & $\begin{array}{l}5.40(1,2,5,6) \\
.12 \\
4\end{array}$ & $\begin{array}{l}4.59(2,3,4,6) \\
.09 \\
5\end{array}$ & $\begin{array}{l}1.87(1,2,3,4,5) \\
.21 \\
3\end{array}$ & $\begin{array}{l}F=70.25 \\
p<.0001\end{array}$ \\
\hline $\begin{array}{l}\text { Competitive } \\
\text { Aggressiveness } \\
\text { Cluster Mean } \\
\text { Std. error } \\
\text { Rank }\end{array}$ & $\begin{array}{l}4.64(2,3,5,6) \\
.15 \\
2\end{array}$ & $\begin{array}{l}2.90(1,3,4,5) \\
.23 \\
5\end{array}$ & $\begin{array}{l}5.32(1,2,5,6) \\
.11 \\
6\end{array}$ & $\begin{array}{l}4.87(2,5,6) \\
.18 \\
5\end{array}$ & $\begin{array}{l}3.93(1,2,3,4,6) \\
.11 \\
6\end{array}$ & $\begin{array}{l}1.92(1,3,4,5) \\
.31 \\
2\end{array}$ & $\begin{array}{l}F=45.47 \\
p<.0001\end{array}$ \\
\hline $\begin{array}{l}\text { Motivation } \\
\text { Cluster Mean } \\
\text { Std. error } \\
\text { Rank }\end{array}$ & $\begin{array}{l}5.54(3,4,6) \\
.16 \\
1\end{array}$ & $\begin{array}{l}6.06(6) \\
.14 \\
1\end{array}$ & $\begin{array}{l}6.48(1,5,6) \\
.06 \\
1\end{array}$ & $\begin{array}{l}6.40(1,5,6) \\
.08 \\
1\end{array}$ & $\begin{array}{l}5.73(3,4,6) \\
.11 \\
1\end{array}$ & $\begin{array}{l}3.28(1,2,3,4,5) \\
.39 \\
1\end{array}$ & $\begin{array}{l}F=43.16 \\
p<.0001\end{array}$ \\
\hline
\end{tabular}

Note: The numbers in parentheses show the group number(s) from which this group was significantly different at the 0.05 level of significance, based on the Tukey HSD pairwise tests. The rank indicates the rank order of this characteristic within the cluster.

SCALE: 1 - Strongly Disagree / 7 - Strongly Agree 
Table 5: Pharmacy Types by Clusters

\begin{tabular}{|c|c|c|c|c|c|c|c|}
\hline $\begin{array}{l}\text { Pharmacy } \\
\text { types }\end{array}$ & $\begin{array}{l}\text { Competitive } \\
\text { Aggressors } \\
\mathrm{n}=31 \\
\text { Cluster \#1 }\end{array}$ & $\begin{array}{l}\text { Ambitious } \\
\mathrm{n}=23 \\
\text { Cluster \#2 }\end{array}$ & $\begin{array}{l}\text { True } \\
\text { Entrepreneurs } \\
n=76 \\
\text { Cluster \#3 }\end{array}$ & $\begin{array}{l}\text { Low-risk } \\
\text { Entrepreneurs } \\
n=35 \\
\text { Cluster \#4 }\end{array}$ & $\begin{array}{l}\text { Proactive } \\
\text { Innovators } \\
n=69 \\
\text { Cluster \#5 }\end{array}$ & $\begin{array}{l}\text { Anything but } \\
\text { Entrepreneurs } \\
\mathrm{n}=13 \\
\text { Cluster \#6 }\end{array}$ & $\begin{array}{l}\text { Frequency / } \\
\text { Percent }\end{array}$ \\
\hline Independents & $7 \%(23 \%)$ & $5(22)$ & 43 (59) & $13(40)$ & $29(45)$ & $3(23)$ & $\begin{array}{c}105 \\
43 \%\end{array}$ \\
\hline Small Chain & 9 (6) & $13(13)$ & $30(9)$ & $13(9)$ & $30(10)$ & $4(8)$ & $\begin{array}{c}23 \\
9 \%\end{array}$ \\
\hline Large Chain & $21(35)$ & $13(30)$ & 19 (13) & $21(31)$ & 23(17) & $4(15)$ & $\begin{array}{c}53 \\
22 \%\end{array}$ \\
\hline $\begin{array}{l}\text { Food - Drug } \\
\text { Combo }\end{array}$ & 19 (19) & $16(22)$ & $6(3)$ & 12(11) & 28(13) & $19(46)$ & $\begin{array}{c}32 \\
13 \%\end{array}$ \\
\hline $\begin{array}{l}\text { Mass } \\
\text { Merchandise }\end{array}$ & $18(10)$ & $12(9)$ & $41(9)$ & $12(6)$ & $12(3)$ & $6(8)$ & $\begin{array}{c}17 \\
7 \%\end{array}$ \\
\hline $\begin{array}{l}\text { Outpatient } \\
\text { Hospital }\end{array}$ & $12(6)$ & $6(4)$ & $29(7)$ & $6(3)$ & $47(12)$ & $0(0)$ & $\begin{array}{c}17 \\
7 \%\end{array}$ \\
\hline $\begin{array}{l}\text { Frequency/ } \\
\text { Percent }\end{array}$ & $\begin{array}{c}31 \\
13 \%\end{array}$ & $\begin{array}{l}23 \\
9 \%\end{array}$ & $\begin{array}{c}76 \\
31 \%\end{array}$ & $\begin{array}{c}35 \\
14 \%\end{array}$ & $\begin{array}{c}69 \\
28 \%\end{array}$ & $\begin{array}{c}13 \\
5 \%\end{array}$ & $\begin{array}{c}247 \\
100.0 \%\end{array}$ \\
\hline
\end{tabular}

$x^{2}=47.402$ d.f. $=25$ $\mathrm{p}=0.004$

The numbers in each cell represent the percentage within pharmacy type - across the row, and in parentheses percentage within cluster - down the column. Please note that we lost two cases each from Low-Risk Entrepreneurs and Proactive Innovators because of missing data on pharmacy types. 
Table 6: Environmental and Organizational Characteristics by Clusters

\begin{tabular}{|c|c|c|c|c|c|c|c|}
\hline $\begin{array}{l}\text { Environmental } \\
\text { and } \\
\text { Organizational } \\
\text { Factors }\end{array}$ & $\begin{array}{l}\text { Competitive } \\
\text { Aggressors } \\
\mathrm{n}=31 \\
\text { Cluster \#1 }\end{array}$ & $\begin{array}{l}\text { Ambitious } \\
\mathrm{n}=23 \\
\text { Cluster \#2 }\end{array}$ & $\begin{array}{l}\text { True } \\
\text { Entrepreneurs } \\
\mathrm{n}=76 \\
\text { Cluster \#3 }\end{array}$ & $\begin{array}{l}\text { Low-risk } \\
\text { Entrepreneurs } \\
\mathrm{n}=37 \\
\text { Cluster \#4 }\end{array}$ & $\begin{array}{l}\text { Proactive } \\
\text { Innovators } \\
\mathrm{n}=71 \\
\text { Cluster \#5 }\end{array}$ & $\begin{array}{l}\text { Anything but } \\
\text { Entrepreneurs } \\
\mathrm{n}=13 \\
\text { Cluster \#6 }\end{array}$ & $\begin{array}{l}F=\text { Value } \\
(p=\text { probability })\end{array}$ \\
\hline $\begin{array}{l}\text { Munificence }^{\mathbf{A}} \\
\text { Cluster Mean } \\
\text { Std. error }\end{array}$ & $\begin{array}{l}4.42(3,4,6) \\
.17\end{array}$ & $\begin{array}{l}4.25(3,4,6) \\
.28\end{array}$ & $\begin{array}{l}5.33(1,2,5,6) \\
.13\end{array}$ & $\begin{array}{l}5.28(1,2,5,6) \\
.15\end{array}$ & $\begin{array}{l}4.49(3,4,6) \\
.14\end{array}$ & $\begin{array}{l}2.92(1,2,3,4,5) \\
.44\end{array}$ & $\begin{array}{l}F=13.97 \\
p<.0001\end{array}$ \\
\hline $\begin{array}{l}\text { Competitive } \\
\text { Intensity }^{\mathbf{A}} \\
\text { Cluster Mean } \\
\text { Std. error }\end{array}$ & $\begin{array}{l}5.26 \\
.22\end{array}$ & $\begin{array}{l}4.61(4) \\
.31\end{array}$ & $\begin{array}{l}5.18 \\
.18\end{array}$ & $\begin{array}{l}5.75(2,5) \\
.16\end{array}$ & $\begin{array}{l}4.92(4) \\
.18\end{array}$ & $\begin{array}{l}5.46 \\
.42\end{array}$ & $\begin{array}{l}F=2.39 \\
p<.05\end{array}$ \\
\hline $\begin{array}{l}\text { Environmental } \\
\text { Stability } \\
\text { Cluster Mean } \\
\text { Std. error }\end{array}$ & $\begin{array}{l}3.05 \\
.09\end{array}$ & $\begin{array}{l}2.83(3,4) \\
.14\end{array}$ & $\begin{array}{l}3.24(2,5) \\
.06\end{array}$ & $\begin{array}{l}3.24(2) \\
.09\end{array}$ & $\begin{array}{l}2.99(3) \\
.07\end{array}$ & $\begin{array}{l}2.83 \\
.26\end{array}$ & $\begin{array}{l}\mathrm{F}=3.35 \\
\mathrm{p}<.01\end{array}$ \\
\hline $\begin{array}{l}\text { Organicity }^{\mathbf{A}} \\
\text { Cluster Mean } \\
\text { Std. error }\end{array}$ & $\begin{array}{l}3.75(3) \\
.28\end{array}$ & $\begin{array}{l}3.25(3,5) \\
.27\end{array}$ & $\begin{array}{l}4.67(1,2,6) \\
.16\end{array}$ & $\begin{array}{l}4.22(6) \\
.26\end{array}$ & $\begin{array}{l}4.29(2,6) \\
.17\end{array}$ & $\begin{array}{l}2.81(3,4,5) \\
.50\end{array}$ & $\begin{array}{l}F=6.31 \\
p<.0001\end{array}$ \\
\hline $\begin{array}{l}\text { Adaptability }^{\mathbf{A}} \\
\text { Cluster Mean } \\
\text { Std. error }\end{array}$ & $\begin{array}{l}5.20(2,3,4,6) \\
.12\end{array}$ & $\begin{array}{l}4.36(1,3,4,5,6) \\
.19\end{array}$ & $\begin{array}{l}5.98(1,2,5,6) \\
.09\end{array}$ & $\begin{array}{l}5.97(1,2,5,6) \\
.13\end{array}$ & $\begin{array}{l}5.26(2,3,4,6) \\
.08\end{array}$ & $\begin{array}{l}2.64(1,2,3,4,5) \\
.45\end{array}$ & $\begin{array}{l}F=48.65 \\
p<.0001\end{array}$ \\
\hline $\begin{array}{l}\text { Tolerance for } \\
\text { Ambiguity }^{\mathbf{A}} \\
\text { Cluster Mean } \\
\text { Std. error }\end{array}$ & $\begin{array}{l}3.67 \\
.20\end{array}$ & $\begin{array}{l}3.04(3,5) \\
.30\end{array}$ & $\begin{array}{l}3.87(2,4) \\
.18\end{array}$ & $\begin{array}{l}3.09(3,5) \\
.24\end{array}$ & $\begin{array}{l}3.87(2,4) \\
.12\end{array}$ & $\begin{array}{l}4.00 \\
.39\end{array}$ & $\begin{array}{l}F=3.19 \\
p<.01\end{array}$ \\
\hline
\end{tabular}

Note: The numbers in parentheses show the group number(s) from which this group was significantly different at the 0.05 level of significance, based on the Tukey HSD pairwise tests.

Scale A: 1 - Strongly Disagree / 7 - Strongly Agree

Scale B: 1 - Very Low / 5- Very High 
Table 7: Outcome Measures by Clusters

\begin{tabular}{|c|c|c|c|c|c|c|c|}
\hline $\begin{array}{l}\text { Outcome } \\
\text { Measures }\end{array}$ & $\begin{array}{l}\text { Competitive } \\
\text { Aggressors } \\
\mathrm{n}=31 \\
\text { Cluster \#1 }\end{array}$ & $\begin{array}{l}\text { Ambitious } \\
\mathrm{n}=23 \\
\text { Cluster \#2 }\end{array}$ & $\begin{array}{l}\text { True } \\
\text { Entrepreneurs } \\
\mathrm{n}=76 \\
\text { Cluster \#3 }\end{array}$ & $\begin{array}{l}\text { Low-risk } \\
\text { Entrepreneurs } \\
\mathrm{n}=37 \\
\text { Cluster \#4 }\end{array}$ & $\begin{array}{l}\text { Proactive } \\
\text { Innovators } \\
\mathrm{n}=71 \\
\text { Cluster \#5 }\end{array}$ & $\begin{array}{l}\text { Anything but } \\
\text { Entrepreneurs } \\
\mathrm{n}=13 \\
\text { Cluster \#6 }\end{array}$ & $\begin{array}{l}\mathrm{F}=\text { Value } \\
(\mathrm{p}=\text { probability })\end{array}$ \\
\hline $\begin{array}{l}\text { Effectiveness }^{\mathbf{A}} \\
\text { Cluster Mean } \\
\text { Std. error }\end{array}$ & $\begin{array}{l}4.69(3,4,6) \\
.18\end{array}$ & $\begin{array}{l}4.72(3,4,6) \\
.23\end{array}$ & $\begin{array}{l}5.42(1,2,5,6) \\
.09\end{array}$ & $\begin{array}{l}5.56(1,2,5,6) \\
.15\end{array}$ & $\begin{array}{l}4.73(3,4,6) \\
.12\end{array}$ & $\begin{array}{l}3.02(1,2,3,4,5) \\
.47\end{array}$ & $\begin{array}{l}F=16.85 \\
p<.0001\end{array}$ \\
\hline $\begin{array}{l}\text { Customer } \\
\text { Orientation }^{\mathrm{A}} \\
\text { Cluster Mean } \\
\text { Std. error }\end{array}$ & $\begin{array}{l}5.53(3,4,6) \\
.11\end{array}$ & $\begin{array}{l}5.27(3,4,6) \\
.11\end{array}$ & $\begin{array}{l}6.10(1,2,5,6) \\
.06\end{array}$ & $\begin{array}{l}6.14(1,2,5,6) \\
.10\end{array}$ & $\begin{array}{l}5.61(3,4,6) \\
.08\end{array}$ & $\begin{array}{l}4.31(1,2,3,4,5) \\
.41\end{array}$ & $\begin{array}{l}F=21.71 \\
p<.0001\end{array}$ \\
\hline $\begin{array}{l}\text { Growth }^{\mathbf{B}} \\
\text { Cluster Mean } \\
\text { Std. error }\end{array}$ & $\begin{array}{l}2.03 \\
.14\end{array}$ & $\begin{array}{l}2.00 \\
.13\end{array}$ & $\begin{array}{l}2.31(5,6) \\
.09\end{array}$ & $\begin{array}{l}2.03 \\
.12\end{array}$ & $\begin{array}{l}1.86(3) \\
.08\end{array}$ & $\begin{array}{l}1.62(3) \\
.24\end{array}$ & $\begin{array}{l}\mathrm{F}=3.74 \\
\mathrm{p}<.01\end{array}$ \\
\hline $\begin{array}{l}\text { Innovative }^{\mathrm{C}} \\
\text { Services } \\
\text { Provided } \\
\text { Cluster Mean } \\
\text { Std. error }\end{array}$ & $\begin{array}{l}3.64(3,4) \\
.29\end{array}$ & $\begin{array}{l}2.95(3,4,5) \\
.36\end{array}$ & $\begin{array}{l}5.00(1,2,6) \\
.22\end{array}$ & $\begin{array}{l}4.97(1,2) \\
.33\end{array}$ & $\begin{array}{l}4.28(2) \\
.22\end{array}$ & $\begin{array}{l}3.38(3) \\
.62\end{array}$ & $\begin{array}{l}F=6.78 \\
p<.0001\end{array}$ \\
\hline
\end{tabular}

Note: The numbers in parentheses show the group number(s) from which this group was significantly different at the 0.05 level of significance, based on the Tukey HSD pairwise tests.

Scale A: 1 - Strongly Disagree / 7 - Strongly Agree

Scale B: 1 - Less / 3 - More

Scale C: Out of a total of 10 innovative services provided 
Scales in the Survey:

\section{Appendix}

Indicate the number that best shows your agreement with that statement.

1-Strongly Disagree 2-Moderately Disagree ... $\quad 6$-Moderately Agree 7-Strongly Agree

Risk Taking ( $\alpha=.92)$

RISK1: Taking gambles is part of our strategy for success.

RISK2: We take above average risks in our business.

RISK3: Taking chances is an element of our business strategy.

RISK4: Our strategy can be characterized by a strong tendency to take risks.

Innovativeness $(\alpha=.91)$

INNOV1: Our pharmacy is known as an innovator among pharmacies in our area.

INNOV2: We promote new, innovative services in our pharmacy.

INNOV3: Our pharmacy provides leadership in developing new services.

INNOV4: Our pharmacy constantly experiments with new services.

\section{Motivation $(\alpha=.82)$}

MOTIV1: We consider ourselves as having high motivation toward work.

MOTIV2: Our employees are a group of hard working individuals.

MOTIV3: At our pharmacy, we are very ambitious about our work.

MOTIV4: At our pharmacy, we like challenges.

Proactiveness $(\alpha=.89)$

PROACT1: Our pharmacy usually takes action in anticipation of future market conditions.

PROACT2: We try to shape our business environment to enhance our presence in the market.

PROACT3: Because market conditions are changing, we continually seek out new opportunities.

PROACT4: We consistently try to position ourselves to meet emerging demands.

\section{Competitive Aggressiveness $(\alpha=.85)$}

COMPAG1: We directly challenge our competitors.

COMPAG2: We are responsive to maneuvers of our rivals.

COMPAG3: Our actions toward competitors can be termed aggressive.

COMPAG4 : We always respond to actions of our competitors.

\section{Autonomy $(\alpha=.84)$}

AUTON1: New service ideas suggested by employees are acted upon by decision makers.

AUTON2: Management approves of independent activity by employees to develop new services.

AUTON3: Identifying new business opportunities is the concern of all employees.

AUTON4: All employees are encouraged to develop ideas for new service.

\section{Competitive Intensity $(\alpha=.90)$}

\section{Environmental Factors}

COMPIN1: There is substantial competition among pharmacies in our area.

COMPIN2: Our local market is noted for competition between pharmacies.

COMPIN3: Competition among pharmacies in our market is intense.

COMPIN4: There are promotional wars among pharmacies in our local market. 


\section{Munificence $(\alpha=.86)$}

MUNIF1: There are ample opportunities for growth in our pharmacy's business environment.

MUNIF2: Our business environment will support continued growth of our pharmacy.

MUNIF3: Prospects for pharmacy growth in our current business environment are good.

MUNIF4: Our business environment is rich with opportunities for pharmacy growth.

\section{Environmental Stability $(\alpha=.63)$}

Rate the predictability of your pharmacy's business environment.

1 -VeryLow 2-Low 3-Medium 4-High 5-Very High

DYNAM1: The growth of pharmacies in our local market.

DYNAM2: Contract terms with third party payers.

DYNAM3: Services provided to pharmacy customers in our local market.

DYNAM4: The proportion of cash paying customers during the next year.

DYNAM5: The local health care environment next year.

\section{Organicity $(\alpha=.85)$}

\section{Organizational Factors}

For each pair of statements, please circle the number that best represents the management at your pharmacy.

In general, the management philosophy at my pharmacy favors...

ORGSTR1: Tight formal control based on rules and procedures.

ORGSTR2: A strong emphasis on getting personnel to follow formal procedures.

ORGSTR3: A strong emphasis on getting personnel to adhere to formal job descriptions.
$1 \ldots . .7 \quad$ Coordination through informal relationships based on cooperation.

$1 \ldots \ldots 7$ A strong emphasis on getting things done even if this means disregarding formal procedures.

$1 \ldots . .7 \quad$ A strong tendency to let requirements of the job and the individual's personality define proper on-the-job behavior.

\section{Adaptability ( $\alpha=.87)$}

ADAPT1: We are able to change to meet the needs of our business environment.

ADAPT2: We keep pace with changes required by our business environment.

ADAPT3: We adapt to demands of our business environment.

Tolerance for Ambiguity ( $\alpha=.76)$

TOLAMB1: Management is comfortable handling a vague situation.

TOLAMB2: Our decision makers think that it's OK to have ambiguity present.

TOLAMB3: The managers here can live with an ambiguous situation.

TOLAMB4: Our managers are tolerant of ambiguity about our situation. 
Effectiveness ( $\alpha=.86)$

\section{Performance Measures}

We consistently meet our organizational performance goals.

Our pharmacy always achieves its stated goals.

More often than not, we attain our annual objectives.

\section{Customer Orientation $(\alpha=.65)$}

The welfare of our customers is a primary concern for us.

The customers' interests always come first, ahead of our owners'.

We regularly ask our customers about the value of our services.

Our service development is based on good customer information.

Our success comes from meeting our customers' needs.

\section{Number of Innovative Services Offered:}

Please tell us which, if any, of the following innovative pharmacy services are currently provided at your pharmacy. Answer Yes (Y) or No (N) for each service listed.

PSERV1: Asthma care management.

PSERV2: Specialized compounding.

PSERV3: Patient compliance program.

PSERV4: In-pharmacy immunization.

PSERV5: Formal evaluation of patients' health risks.

PSERV6: Diabetes care management.

PSERV7: Health information materials for patients.

PSERV8: Prospective drug utilization review (DUR)

PSERV9: Phone calls to patients to monitor pharmacotherapy.

PSERV10: Blood tests (e.g. cholesterol levels). 